\title{
CONVERSATIONS
}

Article received on June $4^{\text {th }} 2020$

Article accepted on June $10^{\text {th }} 2020$

UDC: 78.071.1:929 A M.(047.53)

\author{
Jelena Novak* \\ CESEM, Universidade NOVA de Lisboa
}

\section{MUSIC BEYOND HUMAN A CONVERSATION WITH MICHEL VAN DER AA ${ }^{1}$}

My first encounter with the Dutch composer and director Michel Van der Aa's (b. 1970) music was at the Gaudeamus Music Week, when I heard his most recent piece at that time: Here [In Circles] (2002) for soprano, cassette recorder and ensemble. ${ }^{2}$ I remember the soprano Barbara Hannigan in Amsterdam's Paradiso, conscientiously rewinding and fast-forwarding excerpts of her own singing with the ensemble while she continued to sing alongside,

\footnotetext{
* The author's contact details: artina@beotel.net

1 This conversation was audio recorded in Michel Van der Aa'a studio in Amsterdam on 18 September 2019. I am grateful to Katarina Kostić who translated it for the issue of the New Sound in Serbian.

2 Before studying composition (with Diderik Wagenaar, Gilius van Bergeijk and Louis Andriessen), Van der Aa trained first as a recording engineer at the Royal Conservatory in The Hague. In 2002 he broadened his skills with studies in film direction at the New York Film Academy, and in 2007 he participated in the Lincoln Center Theater Director's Lab, an intensive course in stage direction. From Michel van der Aa's official biography at: https://www.vanderaa.net/biography/, Accessed: June 6, 2020.
} 


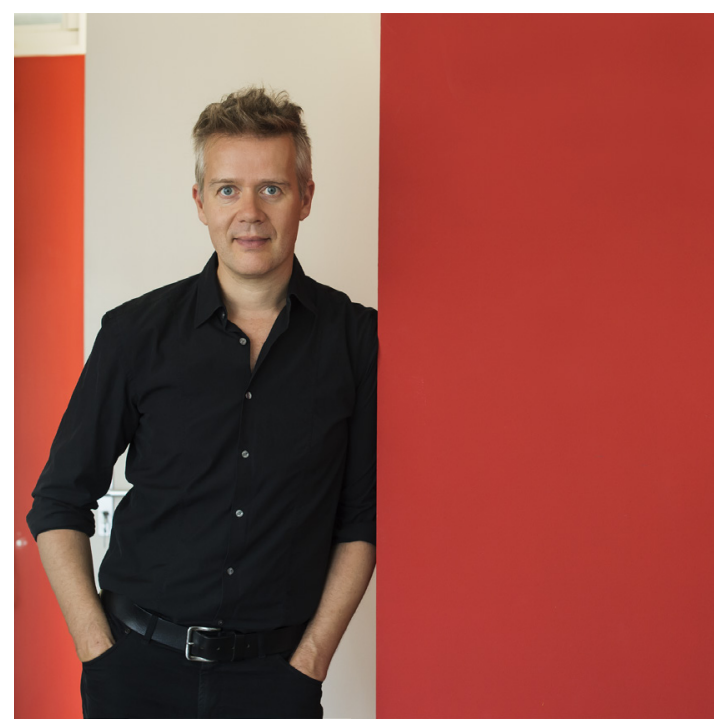

Michel van der Aa

(Photo by Priska Ketterer [2017])

in-between and against the live and recorded sound. This experience called into question not only the conventional status and function of soloists, ensembles and live performances, but also the engagement and perspective of the listening spectator. I remember the unusual aura surrounding that concert performance, as well as the intriguing sense of disturbance that was felt as if all the clichés of singing, performing and listening were elegantly, but irreversibly, dismantled.

When I later encountered other pieces by Van der Aa I continued to be intrigued by his insistence on reinventing borders and challenging the common protocols of the fields in which he works. His creations, even when not belonging to the genre of music theatre or opera, involve a certain multimedia-based theatricality. A typical example is Up-Close (2010) for solo cello, string ensemble and film, in which the film character's destiny seems to be unexpectedly related to the reality of the concert performance itself. In 2003, when I saw Van der Aa's chamber opera One for soprano, video and soundtrack (2002) at Music Biennale Zagreb, it felt as though this unique and disquieting piece sharply intensified the live-mediatized divide I had registered in Here [In Circles]. There was Barbara Hannigan again, this time enmeshing her live singing with her video/audio double to the point at which it was impossible to say where the boundaries of her voice and body were lo- 
cated. The video screen looked like a kind of mirror for the live performer and vice versa. Here [In Circles] seems like a study for the opera One, just as One would later become the prototype of Van der Aa's second and more complex opera After Life (for 6 singers, ensemble, video and electronic soundtrack, 2005-06), based on the film by Hirokazu Kore-Eda. The story of both film and opera is organized around the following question: What was the most decisive moment of your life? Protagonists choose their key moment, and only one chosen memory travels forward with its 'owner' to eternity.

After creating operatic works such as One, After Life, The Book of Disquiet (a music theatre piece for actor, ensemble and film based on the homonymous work by Fernando Pessoa, 2008), and the 3D opera Sunken Garden (2011-2012), Van der Aa accomplished the tour de force of composing, filming, editing, and rehearsing several operas of about one minute in duration, each commenting on certain media and political events. These pieces, commissioned by the Dutch broadcasting network VARA, comprise "With My Ear to the Ground" (2010), "Van het Vergeten" (About Forgetting, 2010), "Willem Holleeder" (2012), "God, Vaderland en Oranje" (God, Homeland and Oranje, 2012), ${ }^{6}$ "Vlucht MH370" (Flight MH 370, 2014), ${ }^{7}$ all designed to be performed live during their talk show. The libretti are in Dutch and the subjects depicted are public events that attracted strong media attention. These miniature operas can also be perceived as intense and brilliant singing caricatures. ${ }^{8}$

Beyond all multimedia interventions in Van der Aa's oeuvre, his poetics may be characterized as an attempt to interrogate identity and its uniqueness, constantly revealing the elusiveness of our sense of identity and the multiple

3 Scored for mezzosoprano (Tania Kross), actor (Thom Hoffman), positive organ (Jeroen Bal); composition, film: Michel van der Aa, libretto: Nico Dijkshoorn.

4 Libretto: Adriaan van Dis; composition, film: Michel van der Aa; design: Maarten Cornet.

5 Text: Tommy Wieringa; music: Michel van der Aa; performers: Tiemo Wang and vocalists VocaalLAB.

6 Libretto: Felix Rottenberg; pictures: Museum Geelvinck Hinlopen Huis aan de Keizersgracht in Amsterdam.

7 Libretto: Beatrice de Graaf; baritone: Martijn Sanders; soprano: Nora Fischer; string quartet: Het Dudok Kwartet; double bass: Marijn van Prooijen; music: Michel van der Aa.

8 I wrote in more details about one-minute operas by Michel van der Aa in: "Singing beyond the TV Screen: Documentary, News and Interviews as Operatic Material”, Dramaturgias, 10, 2019, 91-109. https://doi.org/10.26512/dramaturgias.v0i10 
perspectives from which it might be perceived. This is signalled by the titles of several of his compositions-See-Through for orchestra (2000), Second Self for orchestra and soundtrack (2004), Imprint for baroque orchestra (2005), Mask for ensemble and soundtrack (2006) -all alluding to the multi-faceted nature of identity and calling into question its uniqueness. This quest for identity in Van der Aa's output is intensified in turn by his examination of the impact of new media on composition, by his strategic choice of musical language, and by the economy of the expressive means used.

After composing the 3D opera Sunken Garden and the digital, interactive song cycle The Book of Sand (2015), ${ }^{9}$ Van der Aa intensified his opera-musicmultimedia explorations in his most recent piece-the virtual reality installation Eight (2018-19) - by 'zooming' in on the possibilities of virtual reality in music theatre. Eight lasts for about fifteen minutes, only one person can go through it at a time (you have to reserve a unique time slot to experience it), and there are no live performers. As we enter the curving path of the installation, a virtual woman-the actress and fifties + model Vakil Eelman (who also appeared in Van der Aa's Up-Close) - makes an inviting gesture with her hand to indicate that the visitor should follow her. A bit further down the path a younger version of the same character is embodied by a virtual figure based on the appearance of Kate Miller Heidke. Finally, in a scene under the table, the virtual little girl Livia Kolk sings a capella. I understood all three figures to represent the same character, but at different stages of her life.

Although it was created before the COVID 19 pandemic, Eight's virtual reality, solitary listening / spectating experience and technologically reinvented 'live-ness' strongly resonates with questions that have been raised about the performing arts in an age of isolation. ${ }^{10}$ Recently Van der Aa published the album Time Falling in collaboration with Kate Miller Heidke. It includes music from Eight. This is his first indie-pop album, and it seems to continue the process of questioning those porous borders between popular and classical, human and cyborg, real and virtual, and live and mediatized. ${ }^{11}$

9 The Book of Sand is available at: http://thebookofsand.net/, Accessed: May ${ }^{\text {st }}, 2020$.

10 I wrote about Eight in more details in the text: "Eight, aus Licht, and The Unbearable Lightness of Being Immersed in Opera”, The Opera Quarterly, 35/4, autumn 2019, 358371 https://doi.org/10.1093/oq/kbaa003.

11 Several songs from the album Time Falling are available online: https://disquietmedia.net/catalogue/time-falling/; http://disquietmedia.net/timefalling/ https://www.youtube.com/watch?v=mdB6cwDCgsE; https://www.youtube.com/watch?v =E7FhhdyaCD0; https://www.youtube.com/watch? $\mathrm{v}=\mathrm{I} 3 \mathrm{x} 7 \mathrm{xQwgBdg}$

Accessed: June $21^{\text {st }}, 2020$. 
Your latest piece is the virtual reality installation Eight, which I saw at Muziekgebouw aan't IJ in Amsterdam in 2019. I knew that it is supposed to be seen by one person at a time, but I didn't expect that I would be kind of alone in the building. There was a lady at the entrance. She told me where to go and then I realized that I was alone there. It became kind of creepy but also interesting. There is often a certain loneliness in your pieces. Where does this come from? Why it is important for you?

I think it really depends on the audiences if you feel the loneliness in the pieces. Often I focus on the individual stories, on the very humanistic stories, stories that are about larger themes in life. Loneliness is definitely one of those themes, for example people who are at the edge of life, like in After Life. I think I really like this confrontation with yourself in a piece. When you enter Eight there's the woman that you meet and during these fifteen minutes you work out a relationship with her. This journey is part of a larger aesthetics that I have in my work.

So, the 'solitary viewer situation' was definitely pre-conceived for Eight. I was in doubt about it for a day. When I saw Eight it was a public holiday in Holland, so I thought that maybe the building was closed for visitors... Then I asked a colleague who had visited it a few days before and he said it was the same when he was there...

It's such a different way of presenting a work. It's the first VR piece that I did. Of course I did The Book of Sand, which was a digital song cycle online. You can see it behind your computer, which is in your own safe home space. When I walked up to the Muziekgebouw to see Eight, getting up all these stairs, and then there's this chair for you to wait... I love the whole ritual of getting in there. This is something that the designer Theun Mosk and I thought about a lot. How do we want people to get in? How do we get them into this mindset that will work for peace? That's why everybody is just expected to be there early and sit and read the text and be by themselves for a bit in order to become more open to face what they're about to face.

We had a lot of feedback from the audience, also in France and Aix-enProvence when we had the piece there. They asked us every day to write down for each visitor what they thought of the piece. So we had a great log of feedback and I think there were a number of people who didn't have any experi- 
ence with VR before. They were completely flabbergasted by the possibilities of it, by the fact that you lose yourself into this virtual space. But what I liked about it is that most reactions were about this personal journey and not about technology. I don't want technology to be the main subject of my work. It's just a vehicle that allows me to get my themes across. When you work with new technology, there's always that risk that people will go in expecting to be entertained by the VR and not expecting the actual content. For Eight we really wanted to create this world, which is a perfect blend of a virtual space and physical space. We wanted to have this tactile relationship with VR.

We wanted to do a piece about infinity. How can you create infinite spaces? And VR, of course is a perfect vehicle for that. But what we really missed in the VR pieces that we used to see before was that the piece most often makes you sit in a chair, and look around, and that was it. In Eight we wanted to walk around freely and to actually touch things and interact with the space. And this creates this very strange sensation of being in a virtual space, as you can actually touch it. In your brain there is a discrepancy because of it, which we find very interesting.

I think you easily accept being in a fictional space - if you're not really there, if you observe it from a distance. But once you're in there, you have to actually physically walk, touch things to move the story forward. That's a whole different ordeal, and it makes you somehow much more connected to the space, much more connected to the story in a way and creates much more confusion about what was real and what was not real.

I almost walked out. I was so overwhelmed that I felt I couldn't deal with it anymore. Not because I didn't like it, but because I was too excited about it.

We had more people like that. I taught a group of students in Aix-En-Provence who were all directors and film-makers and scenographers and there were two of them that found it also overwhelming. I sort of realized that this is where we're heading. This has much more to do with the way we deal with this second layer in our lives now, instead of dealing with it through a window of your computer. Suddenly it becomes this all-around-experience. And I think our children take it for granted, they take their Apple glasses and they are there, they meet with their friends and they do their games and they live through this. I am one hundred percent convinced that it will be like that in ten years' time. I get excited because it gives me so many new possibilities. I think it's important for artists to be involved in this technology as well, to say what we want to say. 
On the pathway in Eight I encountered details related to your previous works, like the lamp from Up Close or wandering around in a weird space like in One, or meeting some of your heroines from previous pieces like Kate Miller Heidke... There is one layer of interpretation in Eight for someone who sees your work for the first time and another one for those who do know the context of your previous works. That is intriguing: it is like you are all the time creating one piece but dividing it into separate moments.

I like these hyperlinks to other works on the micro-level so to speak, or metalevel. I have been doing this quite a lot in other pieces too. There are always these objects that are returning: the glass jars and the branches, of course...

There was the moment under the table that was from the Book of Sand. And the ghosts that appear in the cave. I think that they are also from The Book of Sand.

Yes. These are the Nederlands Kamerkoor people and they actually carry branches in the forest and they break the branches. That's something I started doing a while ago and I kind of enjoy building up the pyramid like that...

For me as a music critic it was intriguing how you interfered with my way of being when I was there. Normally I would take my notes, and I would decide what I would like to see and how in any particular moment, but in this case, it was quite authoritarian, like 'take it or leave it', or 'you're in or you're out'. So this disturbed me in a way.

There's no way to have a distance, it appears. Or you are in it or you are out.

I tried to disobey when I was under the table. When the cloth fell down I felt claustrophobic and then I decided to be half under the table and half out of it. That offered some relief. But still I couldn't resist more...

What was really challenging for us is that we had to take into account all these possibilities of the things that the audience could do. Like you say, not everybody will sit down under the table. Some people keep standing next to the table. This was built as a game engine, so we had to make parallel options for all the choices a person could make. Somebody would turn around to walk back in the hallway the other way around and not follow our direction, you know, so we had to have a solution for that. So there are so many routes in a way you could take through the piece. But the 'normal' route is of course the preferred one. 
Only later did I suddenly realize that this piece was about me! (not about me personally, but about any of us who saw it). I was the one who was choosing the memory, as in After Life. I was the one who was wandering around as in One. I was the one who was under the table as in The Book of Sand. I was the main character of an opera, and this kind of change of perspective was shocking.

This happens also because we arranged that the characters keep on looking at you. Or they follow where you are with their eyes. If you move, she'll move with you, with her eyes. So there's this connection we tried to create. And on the other hand, one of the most difficult things in Eight was how the characters should look. Initially, we tried to make them super realistic and that didn't work at all. The more realistic we imagined them, the more distant they became. That was the uncanny valley syndrome. At a quite late stage we rolled back on that. I told them: ok, now I want you to glitch about this, I want to have these transparent areas that you can literally see through - seeing the inside, seeing through them, and seeing the space... That for me made them almost elements of the space rather than actual representations of someone. In a way this also connects to what you said. I mean, you being subject of the opera is also because of that. You're the most realistic person in there. And these are all reflections of you and where you are in the space. And the space itself is a very important character. It was going from being closed in the cave, to enormous spaces with enormous views, extreme changes in space. The space is a protagonist.

Most of the time I wasn't focused on music; I think I was overwhelmed. But I remember the atmosphere. However I don't remember the music in a way that I normally do because there were so many other things.

I think that's something I learnt from it. Already while making it I started simplifying the music. I started with very complex ideas. A lot of details, lots of choral music, lots of surrounds. It was way too much. You couldn't cope with it anymore. I decided to go back to a very, very simple, almost indiepop-like-track with abstract moments, a capella choral moments. But overall, some of it is quite direct and quite focused. That's something that we knew from the beginning it would be like: this kaleidoscopic amount of information you give the audience. You don't experience every layer every moment.

And Eight is deceptive in terms of space and time. I know that it lasted about 15 minutes, but the feeling was that it was much longer. Also, I know more or 
less the dimensions of the space. But it felt much more spacious. And the shape of the path must have been the Arabic number eight?

You do walk around 8, but not all the time. It's only half of a circle in there. Literally half of the circle and a little bit of space in front of it.

I thought about the title. Why Eight? I thought that the girl singing in Eight is probably eight, and that the path might be in the shape of the number eight.

It is also 8 in terms of infinity. And eight choir members are there, so the number comes back in lot of aspects of the piece. We actually started it for an actual shape of 8 and then we thought: do we really need this form of the number eight? Because we are working with virtual reality, we can trick the audience into thinking that they are walking in this enormous space.

There is a strong focus on female protagonists in your pieces. In some of the interviews I read, you said it's about your affinity towards the female voice.

It is almost like an unconscious thing. It has to do with the voice for sure. I think in this case, I really wanted to work with Kate Miller Heidke. She felt like the perfect person for this project. Often I link a project to a performer. I think they're amazing performers and that's why I write for them. The next opera I write is for Roderick Williams and Julia Bullock who are completely different characters again. It really depends on the piece, and on the subject.

There is also a kind of almost post-human beauty that your performers have, distanced beauty. Even the fado singer Ana Moura in The Book of Disquiet - a completely different character - somehow started looking as if she is a genuine part of Michel van der Aa's universe.

Maybe I'm looking for this archetypical person. In The Book of Disquiet it had to do with the text of Fernando Pessoa. I really don't have a clear answer to this question. It's very much instinctive. I think in Eight we tried to make them really look timeless in a way.

On the other hand, the male characters are also vulnerable and often somewhat tragic characters. In your one-minute television operas unusual male characters are brought centre stage - the right wing politician Geert Wilders, the pilot of the flight MH 370, the Malaysia Airlines plane that disappeared, or the Chilean miner who was trapped underground for weeks. 
Also, vulnerable women. Maybe this circles back to the humanistic themes. I want to see a piece where they can relate on a personal level and I would like to bring them to a state where for each one of them I will have his or her own memories or links to what they're seeing here. This sounds maybe like an open door. But I think by being sometimes less concrete, you push your characters to the windows but they have to open the windows themselves. I think that my most successful music theatre pieces are the most abstract ones.

The themes that you use, do they have any relationship with personal experiences?

Not that I know of. They are the subjects that have always fascinated me. You know, it is man versus machine, a balance that we are dealing with on a daily basis. And also mortality, and loneliness. I think that each one of us to a certain extent deals with it in our own life and therefore they're for me interesting themes to connect with an audience, things that I think about a lot or things that I feel honest and truthful to share in a way.

When you say humanist I immediately think about post-humanism. What it means to be human is re-thought in relation to 'others', such as machines, monsters, or animals... Through questioning what it means to be a human today I understand your themes as inclined towards post-human horizons.

My next opera is about that. Maybe by confronting people with what it is to be not human you determine what is human. I look for these limitations in order to find the outline of what is a human being. This can be very extreme, as in One. It can be because of VR representations you see of yourself in a way, or it can be because you are thinking about what moment you would choose from your life to take with you to the afterlife. Relating the subject of the opera to the audience and initiating sort of a personal journey for the piece, I think that's the ultimate dream for me as a maker. The subjects of my operas are very much in line with that dream.

How do you understand the process in which the human voice changes? In One I perceived Barbara Hannigan as a kind of cyborg voice where you cannot really decide if the voice is coming from the machine/recording or her body. Can a human body produce that voice? Or can it produce it only with the help of a machine... Are there any other vocal examples that you are intrigued by in these divisions? 
Yes, as in Blank Out. In the first part of the opera we see a woman as she sings single words, completely disconnected. And then records herself. And then this is played back. And an alter ego appears in the 3D film and the live person then asks the words. And finally, whole sentences are appearing. It's a recollecting of a memory of the drowning of her child. This is a very interesting sort of structural event. These are very much links to the emotional content of the story. At these moments the technology works. It makes sense in terms of the larger context of the story. I am looking for the edges where technology confronts the human being. But the function has to be clear. It needs to shine a light on something that I couldn't do otherwise, that I couldn't do without technology. That is a very important starting point for me always.

I connect the figure of the anti-diva to what I call postopera, with the singer providing some kind of different relationship between the body and the voice, a different kind of representation between the body and the voice.

Kate Miller Heidke is such an incredible down-to-earth human being, so nice to work with. In that sense she is also an anti-diva. Maybe this is one of the attractions I have to Kate's voice. I mean, when we first worked together in Sunken Garden, that was a very difficult film shoot, with incredible time pressure and a sort of bizarre schedule. She was so incredibly open minded and super positive - an amazing singer, but also an absolutely wonderful collaborator. And the same is true for Roderick Williams, who has the same kind of super positive, open-minded attitude to collaboration, which I really need as a creator to feel free to write. I don't want to feel boxed in by the performer. You have to have this understanding.

There is the adjective 'operatic'. We all use it sometimes. It's intriguing that if you ask someone what is operatic, you get unclear answers. What is 'operatic' for you?

Maybe sort of larger-than-life emotions, which I try to avoid because actual life matters are big enough. I think it has to do with the exaggeration of what was needed in the old days, because of the distance to the audience, and the way the opera was staged. That type of performer is still very much needed in that repertoire. But in the new repertoire, we're looking for a different type of performer, and in that sense operatic becomes something different for new creative artists, I think. 
And is there anything without which opera cannot exist? Is there any essential element that must be there?

There needs to be singing. It would be nice not to have those restrictions.

Recently you founded DoubleA Foundation. One of its tasks is to reinvent what opera can be today.

In my work, I come across interesting new collaborators all the time. And I thought, well, you've got to formalize that a little bit more. As a maker, you need to be able to do research and to take risks. And I found that when I come up with a new project I already have to decide on the technology that I will use early on. Then you find your partners and you start making it. When you're making it, you run into walls, and sometimes you need to do things differently and things become more expensive or you need to have another team. After some time this became such a hurdle for me that I wanted to disconnect the pre-production process from the actual product, actual performance. So this is one of the reasons I reset as a DoubleA so we can do research and development with a lot of different people and come with ideas that sometimes will lead to an actual production and sometimes not. It's also a schooling system for young professionals to tour internationally and to work on a very high level and to learn from people who have done that already.

I understand some of your pieces as political statements, although they're not overtly political. But for example, Eight in that sense could also be read through the lens of power relations.

We had to find a lot of smaller departments in order to produce it, as it doesn't really fit anywhere. It's not a live performance for my publisher, for example. And it's not a pre-recorded experience either, because it's very interactive...

For the gallery, it might be too performative...

Exactly. And also the music is not 'pure' contemporary, it is indie-pop, or it is too short or whatever, you can find other things. And also there are certain types of reviewers who go to see my work, and immediately they start separating the layers... And I think there's only one way to experience a piece like this: to see it as a whole of interconnecting parts. 
This happens also because most often, critics come from one single field, and they might be afraid of getting out of their comfort zone...

If you see the works nowadays, they are more and more multimedia. I don't like the term cross-genre because it implies that you have to actually cross certain boundaries and I don't really see the boundary anymore, so there's no crossing needed. It's all there. So that's an interesting question.

So Eight questions power relations?

Not actively but it's a natural result of the choices I make. And in that sense, the piece starts fitting in less and less. And then this is something I do feel and this is one reason we started the foundation in order to gain control again in our situation. In my perfect world, I would be able to produce my own works and sell them to people who want to have them and not be dependent on opera houses or festivals anymore as co-creators. The same is true of releasing CDs. I'm really wondering whether I should release any more hard copies. This is all because nobody buys them anymore.

I'm now finishing a new album with tracks from Eight. It will be an indie-pop sound. I'm very biased. It's definitely contemporary, but not in the way we used to think. I can't send it to classical critics because it's really not up their alley... I've become less and less comfortable with all these divisions. It is about the decisions I made in my works, the types of work I make. It becomes very difficult for this type of work to fall into any particular category. This is their strength and weakness at the same time.

You also made five one-minute operas for television, small but deep pieces. I understand them as critiques, even caricatures of how we live today in capitalist realism. The characters are Geert Wilders, Willem Holleeder, and the former Dutch queen Beatrix, among others. Those one-minute operas are more openly political statements.

Yeah, I think the MH 370 Flight is the last one they ever did, which is a pity because it is probably the most watched TV show in Holland. It gave me a new audience also. People saw me and heard me and came to my shows after that. On the other hand when I see those pieces again, being a perfectionist, I am like "Oh my God", we could have done it so much better.

It was a kind of experiment... 
Yes, but when you put them online people don't know that. You need to know the context of them in the show.

It was interesting to see this kind of One setting in one-minute opera with the queen character.

They called me and said: Can you do this with the queen tonight? They call in the morning and then we have to shoot it and then edit the film. I have to write the music and then rehearse it in the afternoon live in the studio. And then in the evening it goes live. Nora (Nora Fischer, the singer, J.N.) pretty much had to do it in one go. It is so stressful!

Did they suggest the subjects of the operas, or did you pick them up?

Yes, they suggested it. When I did a few I had a way in and I sometimes suggested something to them. There was Jochem Valkenburg who was still there and commissioned the Chilean miners piece, and I suggested the last one, the flight MH 370. They didn't do an opera for a long time and I thought that was an important possibility, so it was going back and forth.

It seems that more and more people from different art fields are becoming interested in opera. For example Venice Biennale last year gave an award to the operatic installation Sun and Sea, There are many more installations that take opera as their theme, for example Opera of Prehistoric Creatures by Marguerite Humeau. Why do you think there is this increased interest in opera nowadays?

It allows for all these things to happen. Whether you call it music theatre or opera I don't mind, but it's the perfect vehicle to allow for all these layers of media to create a ritual in time together with an audience and storyline that become very personal. I can imagine why people choose it. If you look at contemporary opera, this is going well, in terms of commissions and new productions ...

There are also two different worlds of opera, conventional opera, and postopera if you wish, just as there is classical ballet and modern dance...

I think opera will move increasingly to festivals rather to opera houses for productions of new opera. I think there's a shift that has been going on for a long time. And I think it will be more and more clear, given the situation that 
I and other creative artists are in, that if your self-produce your work it's easier to get festivals to take it then opera houses, because you already offer them your whole production trajectory. I think there's a shift probably going on there. Festivals like Opera Forward or Operadagen Rotterdam are way more interesting than the opera houses. That's where the adventure happens. They also in a way move it outside of the normal structure. It's places like the Festival d'Aix, NY Armory, or the Lucerne Festival where super exciting things are happening, not opera houses.

If you are an intendant of an Arts Festival or music festival, you are less restricted in what you can choose. You can react very fast. And in an opera house or in the orchestra you have to plan three years ahead. These kinds of time span encourage a more retrospective approach...

Is there anything from the opera tradition that you took with you as a kind of special memory or influence? I remember seeing you at Stockhausen's Aus Licht last year at the Holland Festival...

I never really enjoyed conventional opera. And also I'm like really not into Stockhausen at all. But in Aus Licht suddenly something happens and you think this is the most brilliant thing ever. It moves between these extremes for me but in the end as a whole, I loved being there. It was also an amazing production. It was great to see all these conservatory students, who were working on it for three years. It was so moving to see the dedication of these people. We have to support that, of course. I go to opera regularly, not a lot but regularly, either to see composers that I like or to follow directors that I like - Simon McBurney, for example. When he does something I try to see it. I am aware of what's happening. But I enjoy plays and dance as much as I enjoy opera and film.

How about your film influences?

I'm a huge fan of Charlie Kaufman's screenplays and his films. I love his mind, also David Lynch, definitely, and Atom Egoyan. Those are some of the film directors that I like. But I also enjoy some Netflix binge-watch series. We're watching succession now. I think a lot of interesting stuff is going to move from film to TV series.

Is it true that your parents had a small opera house? 
Yes, an operetta house. I sang there when I was between seven and ten years old. I started as an extra somewhere in the back and later I had single roles.

So you were pre-destined to write music theatre?

Oh, definitely, my love for theatre absolutely was born there. It was in a small village in northern Holland. I saw people in the village come together and in their free time paint mountains on the backdrops and make fire from the runner fan with strips of paper and a red lamp, an image I used in After Life. That aspect of music theatre when you have very simple objects that become something super-poetic like these moments that are filmed in After Life. Or in Blank Out the woman recreates her own house, looking not only at the high end part of the film output but also making the physical screen surface and the live creation of the footage another layer of 'reality' in the work. The screens in my work are always more than screens, the same way the VR walls are not only virtual walls but they are actually there. Screens and afterlives are magnifying glasses through which we see the memories of the people.

Let me ask you your question at the end: What was the most decisive moment of your life?

I was nine years old and we lived in an old house in Schoorl in northern Holland. It was at the beginning of the summer holiday. The summer holiday lasted six weeks, an eternity for a child. So there was all this free time and freedom, and my mom always used to make pancakes on Saturday evenings. Our house was on the edge of the dunes. We were playing hide-and-seek with the neighboring children and I was hiding behind my favorite shrub. I was smelling the pancakes already and knowing that there were six more weeks of holiday ahead of me. That was sort of the perfect feeling of belonging: happiness, freedom, uncomplicated sort of possibilities, eternity. If I were to choose a moment to stay in forever and ever it would be that one, with that mindset, with eternal possibilities, and with time suspended.

$$
* * *
$$

The article was made with the support of CESEM - Research Center for Sociology and Aesthetics of Music, University NOVA Lisbon, FCSH, UID/EAT/00693/2020, with the financial support of FCT through National funds, under the Norma Transitória - DL 57/2016/CP1453/CT0054. 
Чланак примљен 4. јуна 2020.

Чланак прихваћен 10. јуна 2020.

\section{Јелена Новак *}

Центар за студије социологије и естетике музике, Нови универзитет у Лисабону

\section{МУЗИКА ИЗВАН ХУМАНОГ Разговор са Мишелом ван дер Аом'}

Мој први сусрет са музиком холандског композитора и редитеља Мишела Ван дер Аа (Michel van der Aa, 1970) био је на Музичкој недељи Гаудеаму, када сам присуствовала извођењу његовог тада последњег дела Here [In Circles] за сопран, касетофон и ансамбл (2002). Сећам се сопранисткиње Барбаре Хениген (Barbara Hannigan) у амстердамском Парадису која је усредсређено премотавала одломке сопственог певања са ансамблом док је настављала да пева поред, између и против извођеног и снимљеног звука. Ово искуство преиспитало је не само конвенционални статус и функције солисте, ансамбала и живих извођења, већ и ангажман и перспективу 'слушајућег гледаоца'. Сећам се необичне ауре тог концерта као и неочекиваног осећаја узнемирености насталог док су клишеи певања, извођења и слушања елегантно и неповратно размонтиравани.

У каснијим сусретима са другим делима овог аутора остајала сам заинтригирана његовим инсистирањем на преосмишљавању граница и преиспитивању уобичајених протокола поља у којима делује. Његова остварења, чак и када не припадају жанру музичког театра или опере, носе у себи некакву мултимедијалну театралност. Типичан пример је дело Up-Close за соло виолончело, гудачки ансамбл и филм (2010), у коме је судбина филмског лика на неочекиван начин повезана са реалношћу концертног извођења. Када сам 2003. године на Музичком Бијаналу у Загребу видела оперу One за сопран, видео и траку (2002), учинило ми се да је ово јединствено, али и узнемирујуће дело, оштро интензивирало јаз између живе и технолошки посредоване изведбе коју сам запазила у Here [In Circles]. Била је ту опет Барбара Хениген, овога пута утискујући певање у изведбу своје видео/аудио двојнице до момента у коме је било немогуће рећи где су границе између тела и гласа. Видео на екрану је изгледао попут огледала за певачицу која уживо пева и обрнуто. Here [In Circles] је попут студије за оперу One, а One ће касније постати нека врста 'прототипа' за Мишелову другу и комплекснију оперу After Life (за шест певача, ансамбл, видео и траку, 2005-06) засновану на истоименом филму Хироказуа

\footnotetext{
* Ауторкина контакт адреса: artina@beotel.net

${ }^{1}$ Разговор је снимљен у студију Мишела ван дер Аа у Амстердаму, 18. септембра 2019. године. Текст је с енглеског превела Катарина Костић, којој се захваљујем на несебичној помоћи и подршци.
} 
Kope-Еде (Hirokazu Kore-Eda). И филмски и оперски наратив је организован око следећег питања: Који је моменат био пресудан за Ваш живот? Протагонисти одабирају њихов одлучујући животни моменат да би се само једно одабрано сећање придружило свом 'власнику' на путу за вечност.

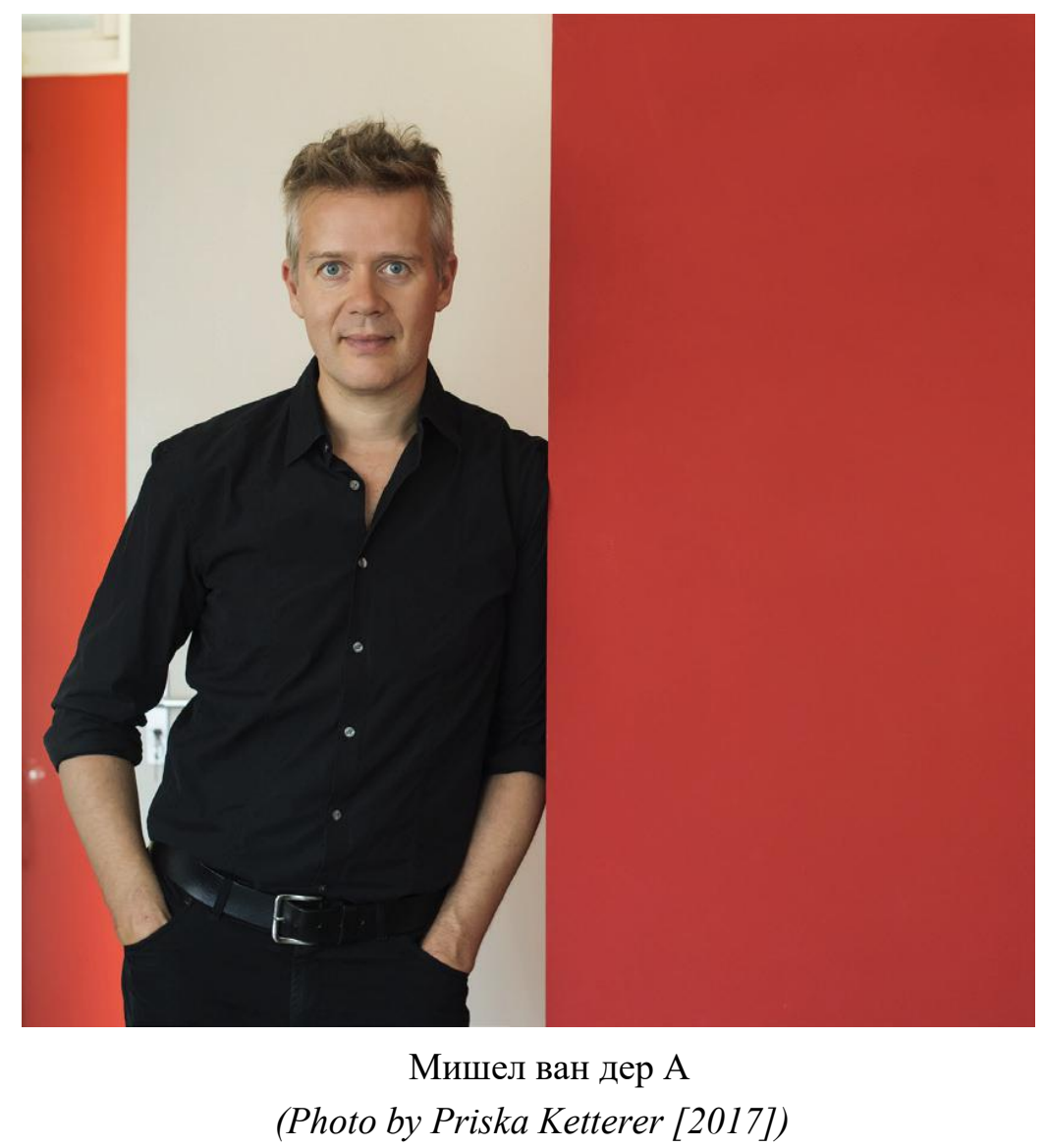

Након стварања опера One, After Life, The Book of Disquiet (дело музичког театра за глумца, ансамбл и филм заснованог на истоименом делу Фернанда Песое (Fernando Pessoa) и 3D oпере Sunken Garden (2011-2012), Ван дер А је остварио tour de force компонујући, снимајући и увежбавајући током једног дана неколико опера које коментаришу медијске и политичке догађаје, свака у трајању од по једног минута. Реч је о једноминутним операма које је наручила медијска кућа ВАРA: With My Ear to the Ground $(2010),{ }^{2}$ Van het Vergeten (2010), ${ }^{3}$ Willem Holleeder (2012), ${ }^{4}$ God, Vaderland en Oranje (2012), ${ }^{5}$ Vlucht MH370 (2014), ${ }^{6}$

\footnotetext{
2 Компоновано за мецосопран (Tania Kross), глумца (Thom Hoffman), позитив (Jeroen Bal); композиција, филт: Michel van der Аа, либрето: Nico Dijkshoorn.

3 Либрето: Adriaan van Dis; композиција, film: Michel van der Aa; дизајн: Maarten Cornet.

${ }^{4}$ Текст: Tommy Wieringa; музика: Michel van der Аа; извођачи: Tiemo Wang и вокални солисти VocaalLAB.

5 Libretto: Felix Rottenberg; уметничке слике: Museum Geelvinck Hinlopen Huis aan de Keizersgracht, Амстердам.
} 
а које су замишљене да буду изведене уживо у телевизијском студију за време трајања talk-show програма. Либрета ових опера су на холандском и теме су везане за јавне догађаје који су привукли велику медијску пажњу. Ове минијатурне опере такође могу бити схваћене и као интензивне и брилијантне певајуће карикатуре. ${ }^{7}$

Узимајући у обзир све мултимедијалне интервенције у опусу Мишела ван дер Аа, његова поетика може бити окарактерисана као покушај да се преиспита идентитет и његова јединственост, константно разоткривајући неухватљивост нашег осећаја за идентитет и разне перспективе из којих се тај проблем може посматрати. То је наглашено и насловима неких од његових композиција: See-Through за оркестар (2000), Second Self за оркестар и саундтрек (2004), Imprint за барокни оркестар (2005), Mask за ансамбл и саундтрек (2006) - See-Through за оркестар (2000), Second Self за оркестар и траку (2004), Imprint за барокни оркестар (2005), Mask за ансамбл и траку (2006) - од којих све алудирају на вишезначну природу идентитета доводећи у питање његову уникатност. Ова потрага за идентитетом у опусу Мишела ван дер Аа је интензивирана његовим преиспитивањем утицаја нових медија на композицију, његовим стратешким избором музичких језика и економијом употребљених изражајних средстава.

Након компоновања 3D опере Sunken Garden и дигиталног интерактивног циклуса песама The Book of Sand (2015), ${ }^{8}$ Ван дер А је интензивирао мултимедијална истраживања опере и музике у најновијем делу - виртуелној инсталацији Eight (2018-19) - зумирајући могућности које пружа виртуелна реалност у музичком позоришту. Eight траје око петнаест минута, само једна особа може да прође кроз инсталацију током њеног трајања (потребно је да закажете време када ћете инсталацију искусити) и у њој нема извођача који музику изводе уживо.

Када ступимо на закривљену стазу инсталације, виртуелна женска фигура - глумица и 'модел за старије' Вакил Еилман (Vakil Eelman, која је била ангажована и у Ван дер Аовом делу $U p$-Close) - позивајућим гестом руке назначава да би посетилац требало да је прати. Нешто даље низ стазу, млађа верзија истог лика је отеловљена у виртуелној фигури заснованој на појави Кејт Милер Хеидке (Kate Miller Heidke). Коначно, у сцени испод стола, виртуелна девојчица Ливија Колк (Livia Kolk) пева a cappella. Сматрам да све три фигуре представљају исти женски лик, али у различитим узрастима.

Иако је Eight настао пре пандемије вируса КОВИД-19, виртуелна реалност, искуство усамљеничког слушања и посматрања, као и технолошки преосмишљено извођење уживо,

\footnotetext{
${ }^{6}$ Либрето: Beatrice de Graaf; баритон: Martijn Sanders; сопран: Nora Fischer; гудачки квартет: Het Dudok Kwartet;контрабас: Marijn van Prooijen; музика: Michel van der Aa.

7 Писала сам детаљније о једноминутним операма овог аутора у тексту „Singing beyond the TV Screen: Documentary, News and Interviews as Operatic Material“, Dramaturgias, 10, 2019, 91-109.

https://doi.org/10.26512/dramaturgias.v0i10

${ }_{8}^{8}$ Дело The Book of Sand је доступно на: http://thebookofsand.net/
} 
снажно резонирају са питањима која се баве извођачким уметностима у доба изолације. 9 Недавно је Ван дер А објавио албум Time Falling у сарадњи са Кејт Милер Хеидке, који укључује музику из Eight. То је његов први инди-поп албум и чини се да њиме наставља процес преиспитивања порозних граница између популарног и класичног, људског и кибернетичког, реалног и виртуелног, живо изведеног и медијски посредованог. ${ }^{10}$

Bame последње дело Eight, инсталацију зановану на виртуелној реалности, гледала сам у сали Muziekgebouw aan’t IJ у Амстердаму. Знала сам да је идеја била да дело види један по један посетилац, али нисам очекивала да ћу, на неки начин, бити сама у згради. На улазу је била једна госпођа која ме је упутила у смер кретања, а затим сам схватила да сам сама. То је, на неки начин, деловало језиво, али и занимљиво. Увек постоји извесна усамљеност у вашим делима. Одакле она долази? Зашто вам је она важна?

Мислим да зависи од публике да ли ће осетити усамљеност у мојим делима. Ја се често обраћам причама о појединцу, причама о људима, причама које говоре о великим животним темама. Усамљеност недвосмислено јесте једна од тих тема, на пример људи који су на ивици живота, као у делу After Life. Мислим да ми се заиста свиђа ово суочавање са самим собом у делу. Када уђете у Eight, сусретнете жену са којом изградите однос током тих петнаест минута. Ово путовање је део шире естетике у мојим делима.

Дакле, „ситуаџија усамљеног гледаоца“ је дефинитивно била претходно осмишљена за Eight. Моја сумьа у то трајала је око један дан. Eight сам гледала у време државног празника у Холандији, па сам мислила да је можда због тога зграда била затворена за посетиоце... Онда сам питала колегу који је гледао Еight неколико дана раније и који је рекао да се исто догодило и када је он био тамо...

У питању је потпуно другачији начин представљања једног дела. То је моје прво дело засновано на виртуелној реалности. Наравно, урадио сам и The Book of Sand, дигитални циклус песама 'online'. Можете га видети на Вашем компјутеру који се налази у Вашем сопственом сигурном простору у кући. Пењао сам се у Muziekgebouw да бих гледао Eight,

\footnotetext{
${ }^{9}$ Писала сам детаљније о Eight у тексту „Eight, Aus Licht, and The Unbearable Lightness of Being Immersed in Opera", The Opera Quarterly, 35/4, autumn 2019, 358-371, https://doi.org/10.1093/oq/kbaa003.

${ }^{10}$ Неколико песама са албума Time Falling је доступно онлајн: https://disquietmedia.net/catalogue/time-falling/ http://disquietmedia.net/timefalling/ https://www.youtube.com/watch?v=mdB6cwDCgsE https://www.youtube.com/watch?v=E7FhhdyaCD0 https://www.youtube.com/watch?v=I3x7xQwgBdg
} 
уз све те степенице, а затим, ту је та столица на којој чекате... Свиђа ми се читав ритуал доласка до тамо. О томе смо дизајнер Теун Моск (Theun Mosk) и ја пуно размишљали. Како бисмо хтели да људи уђу унутра? Како да их убацимо у ментално стање које ће бити примерено делу? Зато је потребно да сви дођу раније и да седе и читају текст, и да буду мало сами са собом како би постали отворенији за сусрет са оним са чим ће се сусрести.

Било је пуно повратних информација које смо добили од публике, такође у Француској, у Екс-ан-Провансу (Aix-en-Provence), када смо тамо постављали дело, сваког дана би нас замолили да запишемо шта би сваки поједини посетилац мислио о делу. Тако да смо имали гомилу повратних информација, а мислим да је постојао известан број људи који нису претходно имали искуства са виртуелном реалношћу. Они су били потпуно запањени могућностима које она пружа, запањени чињеницом да се можете изгубити у виртуелном простору. Али, допало ми се што се највећи део реакција тицао тог личног путовања, а не технологије. Не желим да технологија буде главни предмет мог рада. То је само средство које ми омогућава да остварим своја дела. Када радите са новим технологијама, увек постоји ризик да људи очекују да ће им виртуелна реалност пружити забаву и да не очекују стварни садржај. У делу Eight заиста смо желели да створимо свет који представља савршен спој виртуелног и физичког простора. Желели смо да имамо ту тактилну везу са виртуелном реалношћу.

Хтели смо да направимо комад о бесконачности. Како можете да створите бесконачне просторе? А виртуелна реалност је, наравно, савршено средство за то. Али, оно што смо заиста пропустили да видимо у делима заснованим на виртуелној реалности, а чега смо били свесни раније, јесте то да Вас дело посади у столицу и да ви онда гледате око себе, и то је то. У Eight смо желели да се слободно крећемо и да додирујемо ствари и да ступамо у однос са простором. А то ствара веома чудан осећај постојања у виртуелном свету, када га заправо можете додирнути. У Вашем мозгу се због тога јавља осећај несагласности, а то нам се чинило веома интересантним.

Мислим да лако можете прихватити да се налазите у замишљеном простору - ако нисте заиста тамо, ако га посматрате са дистанце. Али оног тренутка кад уђете тамо, када треба да заправо физички ходате, да додирујете ствари како бисте покретали причу унапред, то је једно потпуно другачије искушење које, некако, утиче да будете у много ближој вези са простором, на неки начин много блискији причи, и то ствара много већу забуну око тога шта јесте а шта није реално.

Замало да сам изашла напоље. Била сам толико преплављена да сам осетила да не могу вите да изађем на крај са свиме. Не зато што ми се није допало, већ зато ито ме је све то превише узнемирило. 
Било је више таквих реакција. Подучавао сам групу студената у Екс-ан-Провансу који су сви били редитељи, филмски ствараоци и сценографи, и двоје међу њима је такође осетило да их је све то преплавило. На неки начин сам схватио да идемо ка томе. Ово има много више везе са начином на који сада излазимо на крај са тим другим слојем у нашим животима, уместо да ступамо у тај однос преко екрана компјутера. Одједном то постаје једно свестрано искуство. Мислим да наша деца то узимају здраво за готово, они ставе своје Apple наочаре и тамо су, срећу се са својим другарима и играју игрице и то живе. Сто посто сам убеђен да ће тако бити за десет година. То ме подстиче, јер ми пружа толико нових могућности. Мислим да је важно да и уметници буду у вези са овом технологијом, да имамо могућност да кажемо оно што бисмо хтели да кажемо.

На стази за кретање кроз Eight, сусрела сам се са детаљима који се појављују и у Вашим претходним делима, попут лампе из Up Close или лутања наоколо у чудном простору као y One, или сусрета са неком од јунакиња из Ваших ранијих дела попут Кејт Милер Хеидке (Kate Miller Heidke)... Постоји један слој за неког ко се први пут сусретне са Вашим делом и други за оне који су упознати са контекстом Ваших претходних дела. То је занимљиво: као да све време стварате једно дело делећи га на раздвојене тренутке.

Допадају ми се ти хиперлинкови са другим делима на микро нивоу, да тако кажем, или мета нивоу. То сам, такође, радио у великој мери и у другом комадима. Увек постоје ти предмети који се поново јављају, стаклене тегле и гране, наравно...

Постојао је тренутак испод стола који је преузет из The Book of Sand. И духови који се појављују у пећини. Мислим да су и они из The Book of Sand.

Да. То су људи из Холандског камерног хора (Nederlands Kamerkoor), и они заправо носе гране у шуми и ломе их. То сам почео да радим пре извесног времена и допало ми се да зидам пирамиду на тај начин...

За мене, као музичког критичара, било је занимльиво како сте се умешали у моје присуство док сам била тамо. Ја бих, у другим ситуаџијама, узела нотес и одлучила шта и како бих волела да видим у одређеном тренутку, али у овом случају, ситуащија је била крајње ауторитарна, попут 'узми или остави', или си унутра или си напољу. То ме је на неки начин узнемирило.

Чини се да не постоји начин да се успостави дистанца. Или сте унутра или или сте напољу.

Док сам се налазила испод стола, покушала сам да не следим сва упутства. Када је покривач пао преко стола, осетила сам се клаустрофобично и затим одлучила да будем 
напола испод стола, а напола ван њега. То ми је пружсио извесно олакшање. Али ипак нисам могла да издржим дуже...

Нама је истински изазов био да узмемо у обзир све те могућности које је публика могла да ради. Као што кажете, неће свако да седи испод стола. Неки људи остану да стоје поред стола. Све је направљено као игрица, тако да је требало направити паралелне могућности за све те изборе које би једна особа могла да учини. Неко би се окренуо да се врати у ходник и крене обрнутим смером и онда смо, знате, морали да имамо решење и за то. Тако да има толико путања којима сте могли да прођете кроз дело. Али, наравно да је била пожељна ‘нормална' путања.

Тек сам касније изненада схватила: ово дело је било о мени! (не о мени лично, већ о било коме од нас који смо га видели). Ја сам била та која је бирала сећање као у делу After Life, ја сам лутала наоколо као у One, ја сам била испод стола као $y$ The Book of Sand, ја сам била главни лик у опери и та врста промене перспективе је деловала шокантно.

То се догодило и као последица тога што ликови све време гледају у Вас. Или прате погледом Ваше кретање. Ако се померите, и они ће се померити са Вама, својим погледом. Постоји та веза коју смо пробали да направимо. А са друге стране, једна од најтежих ствари у Eight била је како осмислити изглед ликова. На почетку смо покушали да им дамо хиперреалистичан изглед, што се показало као потпуно неодговарајуће. Што смо их реалистичније замишљали, то су они више измицали. Попут синдрома сабласне долине. Тек смо се у поодмаклој фази рада вратили на то. Рекао сам људима, у реду, хоћу да мислите о томе, хоћу да имамо транспарентне области кроз које буквално можете да видите, да видите унутрашњост, да видите кроз те области и да видите простор... За мене су то постали готово елементи простора, више него средство за представљање некога. И ово на неки начин има везе са оним што сте рекли. Мислим, то што сте Ви лик у опери је због тога. Ви сте тамо најреалистичнија особа. И то су све Ваши одрази и одрази Ваше позиције у простору. Сам простор је веома битан лик. Идеја се кретала од тога да будете затворени у пећини до огромних простора са огромним видицима, до крајности изведеним променама у простору. Простор је, такође, протагониста.

Највећи део времена нисам била усредсређена на музику, мислим да сам била преплављена свим другим. Али се сећам атмосфере. Међутим, не сећам се музике на начин на који је иначе памтим, јер је било толико других ствари.

Мислим да сам нешто научио из тога. Још у току рада, кренуо сам да поједностављујем музику. Почео сам са веома сложеном партитуром. Пуно детаља, пуно хорске музике, пуно просторног звука. Било је свега превише. Више нисте могли да изађете на крај са 
свим тим. Одлучио сам да се вратим веома, веома једноставној, готово инди-поп мелодији са апстрактним моментима, моментима a cappella хора. Али све у свему, неки делови су прилично директни и прилично усредсређени. То је нешто за шта смо од почетка знали да ће бити тако: та калеидоскопска количина информација коју пружате публици. Не можете да искусите сваки слој у сваком тренутку.

A Eight обмағује и у смислу простора и времена. Знам да је трајао око 15 минута. Али осећај је да је трајао много дуже. Такође, упозната сам мање или више са димензијама простора. Али је деловало много пространије. А облик путање је сигурно имао облик арапског броја осам?

Ходате по осмици, али не све време. Тамо постоји само пола кружнице. Буквално пола круга и мало простора испред.

Размишљала сам о наслову, зашто Eight? Помислила сам да девојчица која пева и Eight вероватно има осам година и да је путаға можда у облику броја осам.

Осам је такође у смислу бесконачности. И има осам чланова хора, број реферира на више аспеката у делу. Заправо смо започели дело са стварним обликом броја осам, а онда смо помислили: да ли нам је заиста потребан овај облик броја осам јер, пошто радимо са виртуелном реалношћу, можемо да преваримо публику да мисли да се креће по том огромном простору.

Постоји велика окренутост ка женским ликовима у Вашим делима. У неким интервјуима прочитала сам да сте рекли да се то тиче Ваше наклоности ка женским гласовима.

То је нешто скоро несвесно. Сигурно је да има везе са гласом. Мислим да сам у овом случају заиста желео да радим са Кејт Милер Хеидке. Она је деловала као савршена особа за овај пројекат. Често доводим у везу пројекат са извођачем. Мислим да су они невероватни извођачи и зато пишем за њих. Следећу оперу ћу радити са Родриком Вилијамсом (Roderick Williams) и Џулијом Булок (Julia Bullock) који су, опет, сасвим другачији ликови. То заиста зависи од дела и од теме.

Такође, постоји готово постхумана лепота коју поседују Ваши извођачи, лепота на дистанци. Чак је и певачища фада Ана Моура (Ana Moura) y The Book of Disquiet - један потпуно другачији лик - некако почела да личи на изворни део универзума Мишела ван дер Aa.

Можда сам у потрази за том архетипском особом. У The Book of Disquiet то је имало везе са текстом Фернанда Песое (Fernando Pessoa). Заиста немам јасан одговор на то питање. 
То радим, у великој мери, инстинктивно. Мислим да смо у Eight заиста покушали да им на неки начин дамо безвремени изглед.

Са друге стране, мушки ликови су такође рањиви и често трагични ликови. У Вашим једноминутним телевизијским операма у центру збивања су својеврсни мушки ликови политичар деснице Херт Вилдерс (Geert Wilders), пилот са лета МН 370 који је отишао са авионом Малезијског авиотранспорта (Malaysia Airlines) или чилеански рудар који је данима био затрпан под земљом...

Рањиве жене, такође, можда то води уназад до тема које се тичу људи. Желим да видим комад према коме људи могу да се односе на личном нивоу, и волео бих да их доведем у стање где бих за сваког од њих имао његова или њена сећања или уодношавања са оним што ту виде. Ово можда звучи као отворен приступ делу. Али мислим да, ако сте понекад мање конкретни, ако само усмеримо своја упутства, публика сама мора да донесе одлуке. Мислим да су моја науспешнија дела за музички театар најапстрактнија.

Да ли теме које користите имају икакве везе са личним искуствима?

Не да сам свестан тога. То су теме које су ме одувек фасцинирале. Знате, то је човек против машине, та равнотежа са којом се суочавамо на свакодневном нивоу. Такође и смртност, усамљеност. Мислим да се свако од нас, на неки начин, суочава са тим у животу и зато су то за мене интересантне теме за публику, ствари о којима пуно размишљам и због којих осећам искрену и истиниту потребу да их поделим.

Када кажете хуманиста, одмах помислим на постхуманизам. Оно што значи бити хуман је поновно схваћено у односу према 'другима', машинама, чудовиштима, животињама... Кроз преиспитивање шта значи бити човек данас, разумела сам да Ваше теме нагињу ка постхуманим гледиттима.

Моја следећа опера је о томе. Суочавајући, можда, публику са оним што се сматра нељудским, одређујемо оно што је људско. Трагам за тим ограничењима како бих пронашао обрисе онога што чини људско биће. То може бити доведено до крајности као у One. Због виртуелних представа себе самих које, на неки начин, видите или због тога што мислите који бисте тренутак из свог живота изабрали да понесете са собом у загробни живот. Мислим да је крајњи сан за мене, као ствараоца, уодношавање теме опере и публике и покретање својеврсног личног путовања кроз дело. Теме мојих опера су у великој мери повезане са тим сном. 
Како гледате на прочес трнасформащије људског гласа? У One сам доживела Барбару Хениган (Barbara Hannigan) као глас киборга за који није могуће одредити да ли долази из машине/са снимка или из њеног тела. Може ли људско тело да произведе такав глас? Или га може произвести само уз помоћ машине... Постоје ли неки други гласовни примери који Вас занимају по питану ових подела?

Да, као у Blank Out. У првом делу опере, видимо једну жену која пева појединачне речи, потпуно неповезане. Затим се снима. А онда се пушта тај снимак. Појављује се алтер его у 3D филму, а присутна особа изговара речи. На крају се појављују читаве реченице, то је прикупљање сећања на утапање њеног детета. Ово је веома занимљива врста структуралног збивања. То су у великој мери умрежавања са емоционалим садржајем приче. Испитујем крајње границе сукобљавања технологије са људским бићем, али то мора да има своју функцију. Мора да баци светло на нешто што иначе не бих могао да урадим, што не бих могао да урадим без технологије. За мене је то увек веома битна исходишна тачка.

Доводим у везу лик антидиве са оним што називам постопером, то је певачица која доноси неку врсту другачијег односа између тела и гласа, другачију врсту представљања односа између тела и гласа.

Кејт Милер Хеидке је једно тако невероватно људско биће са обе ноге на земљи, са којом је веома лепо радити. У том смислу и она је антидива. Можда је то једна од ствари која ме привлачи код Кејтиног гласа. Хоћу да кажем, када смо први пут радили заједно на Sunken Garden, било је то веома напорно филмско снимање, изузетан временски притисак и неочекиван распоред рада. Она је била тако отворена, без предрасуда и супер позитивна, невероватна певачица. Истовремено и потпуно предиван сарадник. А исто важи и за Родрика Вилијамса, иста врста супер позитивног става отвореног за сарадњу, који ми је као ствараоцу заиста потребан како бих имао слободу да пишем. Не желим да осетим да ме је извођач затворио у кавез. Мора да постоји разумевање.

Постоји придев 'оператично'. Сви га понекад користимо. Занимљиво је да ћете, ако упитате некога ита је оператично, добити неодређене одговоре. Шта је за Вас оператично?

Можда врста емоција 'већих од живота' које покушавам да избегнем јер су стварна животна питања довољно велика. Мислим да има везе са претеривањем око оног битног у стара времена, због удаљености од публике, због начина на који је опера постављана на сцени. И даље постоји велика потреба за том врстом извођача у оквиру таквог репертоара. 
Али, у оквирима нових репертоара, трагамо за другачијим типом извођача, у смислу да 'оператично' постаје нешто друго за нове ствараоце, чини ми се.

Да ли постоји ишта без чега опера не може да постоји? Да ли постоји неки суштински елемент који мора да буде присутан?

Певање мора да буде присутно. Било би лепо да не постоје таква ограничења.

Недавно сте основали DoubleA Foundation. Један од задатака ове фондаџије је да преиспита шта опера може бити данас.

Све време мог рада наилазим на занимљиве сараднике. И помислио сам, па морао би да даш неки смисао томе. Треба да будеш у стању да, као стваралац, истражујеш и да прихваташ ризике. Схватио сам да, када искрсне нови пројекат, одмах морам да одлучим коју ћу технологију користити. А онда нађете своје сараднике и почнете да радите. Како рад постепено одмиче, не можете да се залећете у зидове и приморани сте да другачије радите неке ствари, а ствари постају прескупе и морате да мењате екипу. Мени је то, после неког времена, постало велика препрека, да сам желео да одвојим претпродукцијски процес од самог производа, самог извођења. То је један од разлога што сам направио нов почетак са DoubleA, тако да можемо да истражујемо и да радимо на развоју са пуно различитих људи, и да имамо идеје које ће нас понекад одвести то стварне продукције, а понекад и неће. То подразумева, такође, усавршавање младих професионалаца, могућност међународних наступа и рад на веома високом нивоу, учење од људи који су то већ прошли.

Нека Ваша дела схватам као политичке исказе, иако нису отворено политички али се, на пример, Eight у том смислу може читати кроз призму односа моћи.

Треба да нађемо много мањих сектора како бисмо произвели дело, јер се оно не уклапа било где. То није, на пример, живо извођење за мог издавача. А није у питању ни готов снимак, јер је дело веома интерактивно...

За галерију би могао да буде превиме перформативан...

Тачно. А такође, музика није 'чисто' савремена, то је инди-поп, или је прекратка, или шта год, можете рећи и неке друге ствари. А постоји и известан тип критичара који дођу да виде моје дело и одмах почну са анализом раздвајања на слојеве... и мислим да постоји само један начин да се дело тако искуси: да се сагледа као целина међусобно повезаних делова. 
То се догађа и због тога што критичари, најчешће, долазе из свог јединственог поља деловања и могло би их уплашити да изађу из зоне комфора...

Ако гледате дела у данашње време, она су све више мултимедијална. Не волим термин крос-жанр, јер подразумева да сте већ прешли извесне границе, а ја више заиста не видим ту границу, тако да нема потребе за пре(вази)лажењем. Све је ту. Тако да је то занимљиво питање.

Тако да Eight преиспитује односе моћи?

Не директно, али је то природан резултат избора које правим. И у том смислу, дело почне да се уклапа све мање и мање. И то је нешто што осећам и један од разлога што смо основали ову фондацију јесте могућност поновног успостављања контроле над нашом ситуацијом. У мом савршеном свету, могао бих да производим моја сопствена дела и да их продајем људима који хоће да их имају и да више не зависим од оперских кућа или фестивала као коаутора. Исто важи и за издавање дискова. Заиста се питам да ли би требало да издам иједну хард копију више. То је све због тога што их више нико не купује.

Сада завршавам нов албум са нумерама са Eight. Имаће инди-поп звук. Веома сам пристрасан. Дефинитивно је савремен, али не онако како смо навикли. Не могу да га пошаљем критичарима класичне музике, јер то заиста није њихов терен. Све мање ми одговарају све те поделе. То се тиче одлука које сам донео у вези својих дела, врсте дела које правим. Постаје готово немогуће да ова врста дела потпадне под извесну категорију. То је њихова снага и њихова слабост истовремено.

Ви сте, такође, направили пет једноминутних опера за телевизију, малих али дубоких дела. Ја их доживљавам као критике, чак карикатуре нашег живота данас $у$ капиталистичком реализму. Ликови су, између осталих Херт Вилдерс (Geert Wilders), Виліjат Холедер (Willem Holleeder) и холандска краљиия мајка Беатрикс (Beatrix). Те једноминутне опере су у већој мери политички коментари.

Да, мислим да је Лет МН 370 задња коју су урадили, што је штета јер је то вероватно најгледанији ТВ шоу у Холандији. Добио сам и нову публику. Људи су ме гледали, чули су ме и дошли су на моја извођења после тога. Са друге стране, када поново видим те комаде, а како сам перфекциониста, помислим: Боже, могли смо да их урадимо много боље.

То је била врста експеримента... 
Да, али када их ставите 'онлајн', људи то не знају. Морате да знате њихов контекст у емисији.

Било је занимљиво видети ову врсту One-поставке у једноминутној опери са краљицом.

Звали су ме и рекли: Да ли можете да то урадите са краљицом вечерас? Звали су ујутро и затим је требало да снимимо, а онда и монтирамо филм. Требало је да напишем музику, а онда да тог поподнева пробамо уживо у студију. А онда увече иде уживо, Hopa (Nora Fischer, прим. J. Н.) је морала све да уради у једном даху. Било је тако стресно!

Јесу ли они предлагали теме опера или сте их ви одредили?

Да, они су их предлагали. После пар урађених комада, имао сам ближи приступ екипи и понекад бих ја нешто предложио. Још увек је ту био Јохем Валкенбург (Jochem Valkenburg) који је поручио оперу о чилеанским рударима, а ја сам предложио последњу, Лет МН 370. У том моменту, они дуго нису радили нову оперу и помислио сам да је то значајна могућност за ново дело, тако да су предлози ишли од њих ка мени, али и обрнуто.

Изгледа да је све више људи из различитих уметничких области заинтересовано за оперу. Прошле године је, на пример, оперска инсталащија Sun and Sea била награђена на Венеиијанском бијеналу. Постоји још много инсталащија које имају оперу за своју тему, nопут Opera of the Prehistoric Creatures ауторке Маргерит Имо (Мarguerite Huтеаи). Зашто по Вама постоји ово повећано интересовање за оперу данас?

Она дозвољава свим тим стварима да се догоде. Свеједно ми је да ли их називате музичким театром или опером, али то је савршено средство које омогућава свим тим слојевима да направе ритуал у времену заједно са публиком и причом која је постала веома лична. Могу да замислим зашто се људи опредељују за њих. Ако погледате савремену оперу, она добро стоји у смислу поруџбина и нових продукција.

Постоје, такође, два различита света опере, конвенционална опера и постопера, ако хоћете, слично као што постоје класичан балет и модеран плес...

Мислим да ће се опера, у највећој мери, померити ка фестивалима, пре него ка оперским кућама и продуцентима нових опера. Мислим да је већ дуже време у току извесна смена. И мислим да ће то постајати све јасније и због ситуације у којој сам ја и у којој је више стваралаца, а ако сами радите продукцију својих дела, лакше је доћи до фестивала и тамо их извести, него доћи до оперских кућа, зато што већ нудите Вашу целокупну продукциону линију. Мислим да се ту одвија промена. Фестивали попут Opera Forward или Operadagen Rotterdam далеко су занимљивији од оперских кућа, ту се догађа авантура. 
Такође, они су оперу, на неки начин, извукли из нормалних структура. На фестивалима попут Festival d'Aix, NY Armory, Lucerne Festival догађају се супер узбудљиве ствари, а то нису оперске куће. Ако сте учесник на неком уметничком или музичком фестивалу, мање сте ограничени у погледу избора. Можете реаговати веома брзо. А у оперској кући или у оркестру морате да планирате три године унапред, а толико крупнији аршини, заправо, много више гледају уназад.

Постоји ли ишта из оперске традищије што сте понели са собом као неку врсту посебног сећана или утищаја? Са друге стране, сећам се да сам Вас прошле године видела на Штокхаузеновом (Karlheinz Stockhausen) Aus Licht на Холандском фестивалу...

Никада нисам заиста уживао у конвенционалној опери. А, такође, не занима ме ни Штокхаузен. Али у делу Licht нешто се догодило и одједном помислите да је то најбрилијантнија ствар икада. Креће се између тих крајности, по мени, али у целини гледано, допало ми се што сам био тамо, то је била и једна изузетна продукција. Дивно је видети све те студенте конзерваторијума, радили су на томе три године. Било је тако дирљиво видети посвећеност тих људи. Морамо, наравно, да подржимо то. Идем на оперу редовно, не често, али редовно, или идем да видим композиторе које волим, или пратим редитеље који ми се свиђају - Сајмона МекБарнија (Simon McBurney), на пример. Трудим се да видим кад он нешто ради. Свестан сам шта се догађа. Али уживам и у позоришним комадима и плесу исто колико уживам у опери и филму.

Ко је на Вас утицао из филмског света?

Велики сам обожаватељ сценарија и филмова Чарлија Кауфмана (Charlie Kaufman). Волим његов ум, такође и Дејвида Линча (David Lynch), дефинитивно и Атома Егојана (Atom Egoyan). То су неки од филмских редитеља које волим. Али уживам, такође, да 'бинџујем' неке серије на Нетфликсу (Netflix). Сада гледамо једну епизоду за другом. Мислим да ће се доста занимљивих ствари преселити из филма у телевизијску серију.

Да ли је истина да су Ваши родитељи имали малу оперску кућу?

Да, оперетску кућу. Певао сам тамо када сам имао између седам и десет година. Почео сам као статиста у позадини, а касније сам добијао улоге.

Били сте, дакле, предодређени да пишете за музички театар?

О, дефинитивно, моја се љубав према позоришту апсолутно тамо родила. То је било у једном сеоцу на северу Холандије. Виђао сам људе из села како се окупе и у слободно време цртају планине на кулисама и праве ватру од вентилатора са папирним тракама и 
црвеном лампом. Слика коју сам користио у After Life потиче одатле. Тај аспект музичког позоришта, када користите веома једноставне предмете, постало је нешто супер поетично, попут тих момената који су снимљени у After Life. Или у Blank Out, жена поново прави своју кућу, не само у погледу екстравагантног филмског сегмента, већ и стварања површине физичког екрана и стварања снимка уживо још једног слоја 'реалности' у делу. Екрани у мојим делима су увек више од екрана, на исти начин као што зидови виртуелне реалности нису само виртуални зидови, већ су физички присутни. Екрани и загробни животи су увеличавајућа стакла кроз која видимо сећања људи.

Дозволите ми да Вам на крају поставим 'Ваме' питағе: који тренутак је у Вамем животу био одлучујући?

Имао сам девет година и живели смо у старој кући у Скоурлу (Schoorl) на северу Холандије, био је почетак летњег распуста. Летњи распуст траје шест недеља, читава вечност за дете. Та идеја да имате све то слободно време и слободу и моја мама која је увек пекла палачинке суботом увече... Наша кућа је била на ивици дина. Играли смо се жмурке са комшијском децом и крио сам се иза мог омиљеног жбуна. И већ сам осећао мирис палачинки, знајући да је још шест недеља распуста испред мене. То је била врста савршеног осећаја припадања, среће, слободе, некомпликоване врсте разних могућности, вечности. Ако бих морао да бирам тренутак да останем у њему заувек, то би било то стање ума: вечне могућности и заустављање времена.

Са енглеског превела Катарина Костић 